\title{
Single-shot, high-dose rabbit ATG for rejection prophylaxis after kidney transplantation
}

\author{
R.Zietse ${ }^{1}$, E.P.M. van Steenberge ${ }^{1}$, C.J.Hesse ${ }^{1}$, L. B. Vaessen ${ }^{1}$, J.N.M. IJzermans ${ }^{2}$, W. Weimar ${ }^{1}$ \\ ${ }^{1}$ Department of Internal Medicine I, University Hospital Dijkzigt, Dr. Molewaterplein 40, NL-3015 GD Rotterdam, The Netherlands \\ ${ }^{2}$ Department of Surgery, University Hospital Dijkzigt, Dr. Molewaterplein 40, NL-3015 GD Rotterdam, The Netherlands
}

Received: 13 January 1993/Received after revision: 29 March 1993/Accepted: 6 April 1993

\begin{abstract}
We studied the effects of a single intravenous injection of rabbit ATG (RIVM, Bilthoven, The Netherlands) in a dose of $8 \mathrm{mg} / \mathrm{kg}$ body weight administered $6 \mathrm{~h}$ after kidney transplantation on graft survival, rejection incidence, T-cell subsets, and cost-effectiveness. A total of 58 (37 male/21 female) consecutive renal allograft recipients were entered in this trial. Treatment results were compared with 56 patients treated with intravenous cyclosporin (CyA). In all patients concomitant medication consisted of steroids and azathioprine, followed by oral CyA. Following rabbit ATG, T cells (WT31) quickly disappeared from the peripheral blood and a return to greater than $100 / \mathrm{mm}^{3}$ was observed at a median of 7 (range 3-21) days. Graft survival was the same in both groups, as was the incidence of primary nonfunction. The rate of acute rejection was significantly lower in the rabbit ATG-treated patients ( $12 \%$ vs $50 \%$ ). We conclude that a single shot of rabbit ATG is an attractive, easy, and costeffective induction scheme with a low incidence of delayed graft function and acute rejection episodes. A relatively high incidence of vascular thrombosis of the graft, however, warrants further study before this treatment regimen can be generally applied.
\end{abstract}

Key words: Kidney transplantation, ATG - ATG, single shot, kidney transplantation - Rejection, single shot ATG - Single shot ATG, kidney transplantation

\section{Introduction}

Heterologous immunoglobulins to lymphocytes (ALG) or to thymocytes (ATG) are frequently used in organ transplantation as prophylaxis and treatment for acute graft rejection [5-7]. In order to minimize cyclosporin (CyA) effects directly following transplantation, ALG,

Correspondence to: R. Zietse
ATG, or monoclonal OKT3 can be given in sequential treatment schedules. Using this strategy, several authors have reported a decrease in the incidence of delayed graft function in renal transplantation $[6,7]$. In these reports treatment was usually continued for 7-10 days after transplantation. Prolonged treatment with polyclonal immunoglobulins requires an indwelling central venous catheter, which frequently leads to catheter-related sepsis [1]. Furthermore, this treatment is expensive, costing approximately $\$ 4000$ for a 10 -day course. Treatment with $\mathrm{OKT} 3$, at a comparable price, is associated with a high frequency of side effects $[3,8]$.

In an attempt to devise a safe, easy, and cost-effective sequential immunosuppressive protocol with a minimum of side effects, we studied the effect of a single, intravenous, high dose of rabbit ATG (r-ATG), administered $6 \mathrm{~h}$ after kidney transplantation, on graft survival, rejection incidence, total rabbit and specific rabbit anti-T-cell plasma immunoglobulin levels, as well as the effect on T cells in the peripheral blood.

\section{Materials and methods}

\section{Study population}

The patient group consisted of 37 male and 21 female subjects. Only recipients of cadaveric donor organs were included. The mean age was 49.7 years (range 18-73 years). The mean number of mismatches for HLA-ABDR was $1.9 \pm 1.3$. The current panel-reactive lymphocytotoxic antibody level was over $80 \%$ in three patients. The median cold ischemia time was $29 \mathrm{~h} 30 \mathrm{~min}$ (range 16-46 h) with a median second warm ischemia time of $29 \mathrm{~min}(12-45 \mathrm{~min})$. The median follow-up period was 13 months. Controls consisted of 56 consecutive patients who were transplanted just prior to this feasibility study and who did not receive T-cell-directed immunoglobulin prophylaxis apart from cyclosporin $\mathrm{A}(\mathrm{Cy} \mathrm{A})$. All patients were transplanted at our center during a 3-year period. The clinical characteristics of both groups are shown in Table 1. Whenever acute rejection was clinically suspected, a renal biopsy was performed. Only biopsy-proven rejections were analyzed. In order to allow a direct comparison of both groups, only rejection rates in the first 3 months after transplantation are given. 
Table 1. Clinical patient characteristics

\begin{tabular}{|c|c|c|c|}
\hline Patient group & $\begin{array}{l}\text { CyA-treated } \\
(n=56)\end{array}$ & $\begin{array}{l}\text { r-ATG-treated } \\
(n=58)\end{array}$ & $P$ value \\
\hline $\begin{array}{l}\text { Age (years) } \\
\text { Sex }(\mathrm{m} / \mathrm{f}) \\
\text { ABDR-mismatches } \\
\text { PRA }>80 \%\end{array}$ & $\begin{array}{l}42.8 \pm 13.6 \\
25 / 31 \\
2.2 \pm 1.3 \\
2(4 \%)\end{array}$ & $\begin{array}{l}48.4 \pm 16.8 \\
37 / 12 \\
1.9 \pm 1.3 \\
3(5 \%)\end{array}$ & $\begin{array}{l}\text { NS } \\
\text { NS } \\
\text { NS } \\
\text { NS }\end{array}$ \\
\hline $\begin{array}{l}\text { Median ischemia times } \\
\text { Cold ischemia (hours) } \\
\text { First warm ischemia } \\
\text { (min) } \\
\text { Second warm ischemia } \\
\text { (min) }\end{array}$ & $26.5(13-44)$ & $29.3(15-46)$ & NS \\
\hline Diabetes & $2(4 \%)$ & $4(7 \%)$ & NS \\
\hline Retransplantation & $19(34 \%)$ & $13(22 \%)$ & NS \\
\hline
\end{tabular}

\section{Treatment protocol}

$r$-ATG group. All patients received $8 \mathrm{mg} / \mathrm{kg}$-r-ATG (RIVM, Bilthoven, The Netherlands [4]) $6 \mathrm{~h}$ post-transplantation, following administration of $50 \mathrm{mg}$ methylprednisolone and $4 \mathrm{mg}$ clemastine. CyA was started orally on day 5 at a dose of $8 \mathrm{mg} / \mathrm{kg}$ per day divided into two equal doses and was adjusted to obtain plasma trough levels of $50-75 \mathrm{ng} / \mathrm{ml}$. Concomitant immunosuppression consisted of azathioprine ( $1.5 \mathrm{mg} / \mathrm{kg}$ per day) for 5 days and $15 \mathrm{mg}$ of prednisone. $\mathrm{T}$ cells were monitored on days $0,1,3,5,7$, and 14 post-transplantation.

CyA group. CyA was started intravenously at a dose of $2 \mathrm{mg} / \mathrm{kg} 6 \mathrm{~h}$ after anastomosis. From day 3 onwards, $\mathrm{CyA}$ was given orally $(8 \mathrm{mg} / \mathrm{kg})$ in two doses and adjusted to plasma trough levels of $50-$ $75 \mathrm{ng} / \mathrm{ml}$. All patients received azathioprine $(1.5 \mathrm{mg} / \mathrm{kg}$ ) for 5 days and $15 \mathrm{mg}$ of prednisone.

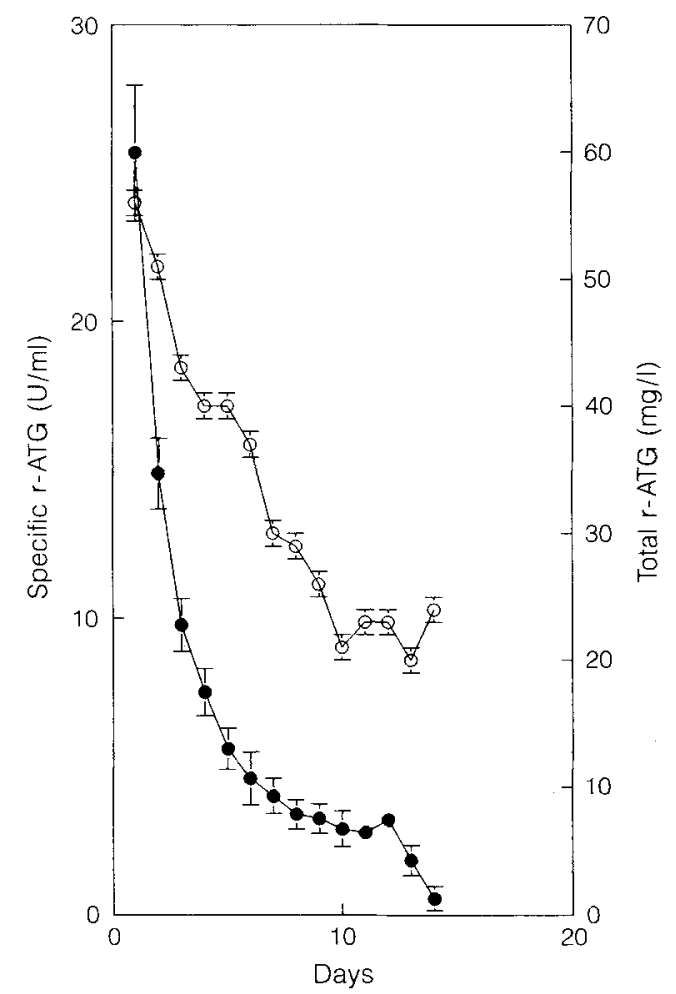

Fig. 1. Plasma levels of total r-ATG measured by ELISA (-O-) and specifically T-cell-directed $\mathrm{r}-\mathrm{ATG}$ as measured by the HPBALL binding assay (- - ) after a single shot $(8 \mathrm{mg} / \mathrm{kg})$ of $\mathrm{r}-\mathrm{ATG}$

\section{Laboratory procedures}

In order to determine the number of circulating $T$ cells, a two-color FACS analysis was performed. In brief, $100 \mu$ l heparinized whole blood was incubated for $30 \mathrm{~min}$ with $20 \mu \mathrm{l}$ of a monoclonal antibody $(\mathrm{mAb})$ combination conjugated directly to fluorescein isothiocyanate (FITC) or phycoerythrin (PE). The $\mathrm{mAb}$ combinations used were: LeucoGATE (CD45/CD14), $\operatorname{IgG}_{1} / \operatorname{IgG}_{2 \mathrm{a}}$ control and WT31/CD5 (Becton \& Dickinson, Mountain View, Calif., USA). WT31 is directed against the $\alpha / \beta$ chain of the T-cell receptor and was, therefore, used as a pan T-cell marker. Data were acquired on a FACScan using Simulset software (Becton \& Dickenson) to establish a lymphocyte analysis gate that included at least $95 \%$ of the lymphocytes and that was contaminated by no more than $10 \%$ of monocytes, granulocytes, or debris. At least 2000 lymphocyte events were acquired from each tube. Total $\mathrm{r}$-ATG plasma was measured using a sandwich ELISA method. Microtiter plates were coated with goat anti-rabbit IgG (Pierce, Rockford, Ill., USA). Following incubation with $0.1 \mathrm{ml}$ samples of diluted plasma $(1: 200)$ or r-ATG (1$3000 \mathrm{ng} / \mathrm{ml}$ ), bound rabbit IgG was estimated with alkaline phosphatase-conjugated goat anti-rabbit IgG (Pierce).

Specific $\mathbf{r}$-ATG in plasma was determined in a cell-binding assay on a human tumor T-cell line (HPB-ALL). Plasma samples (diluted $1: 3,1: 10$, and $1: 30)$ or $\mathrm{r}$-ATG $\left(1: 3.10^{2}-1: 3.10^{6}\right)$ as reference were incubated with $5.10^{5} \mathrm{HPB}-\mathrm{ALL}$ cells. After washing, FITC-conjugated donkey anti-rabbit IgG (Pierce) was added and cells were analyzed by flow cytometry (FACScan) with logarithmic amplification of the fluorescence signal. Results were expressed in arbitrary units assuming there was $100 \mathrm{U} / \mathrm{ml}$ in the original batch of $\mathrm{r}$-ATG.

\section{Statistical analysis}

The clinical characteristics of the two groups and the differences in treatment outcome between the r-ATG and control groups were compared using the unpaired $t$-test or chi-square test for $2 \times 2$ tables where appropriate. Survival data were assessed using actuarial lifetable analysis. Survival times were compared using the log-rank test. A $P$ value less than 0.05 was considered significant in all tests. All data are expressed as mean \pm SD.

\section{Results}

The two treatment groups were highly comparable with regard to the distribution of sex, diabetes, retransplantation, ischemia times, and the mean number of mismatches for the HLA-ABDR loci.

Following treatment with $\mathrm{r}$-ATG, we observed fever (temperature $>38^{\circ} \mathrm{C}$ ) and/or chills in $59 \%(35 / 58)$ of the patients. No episodes of catheter-related sepsis, bronchospasm, or hypotension were observed. Serum sickness was observed in four patients on days 8-15 after treatment; this responded rapidly to treatment with steroids. Urinary tract infection occurred in $27 \%(16 / 58)$ of the patients. Evidence of cytomegalovirus (CMV) disease, defined as fever over $38^{\circ} \mathrm{C}$ and seroconversion, was found in $8 \%$ $(5 / 58)$ of the patients, which was not different from that in the CyA group.

Following the single dose, total r-ATG levels decreased with a plasma half-life of 7.2 days. Specific r-ATG decreased much more rapidly with a plasma half-life of 1.2 days for the first 3 days after transplantation and a half-life of 3.3 days during the subsequent period (Fig. 1). T cells (WT31) quickly disappeared from the circulation 


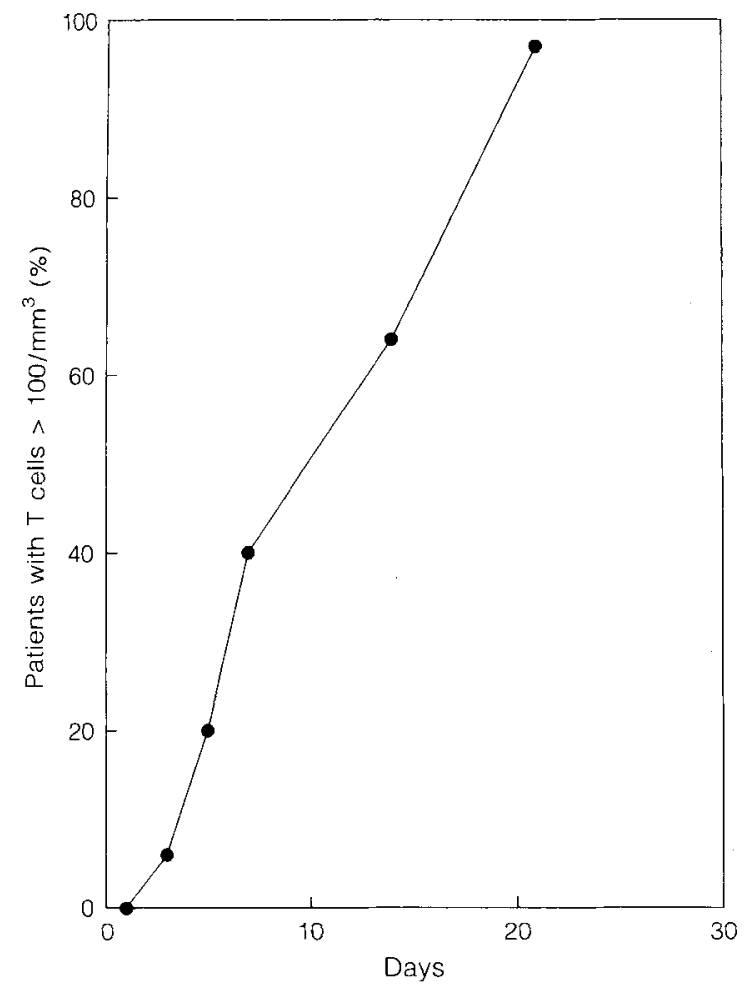

Fig.2. Reappearance of circulating $\mathrm{T}$ cells after a single shot $(8 \mathrm{mg} / \mathrm{kg})$ of $\mathrm{r}-\mathrm{ATG}$

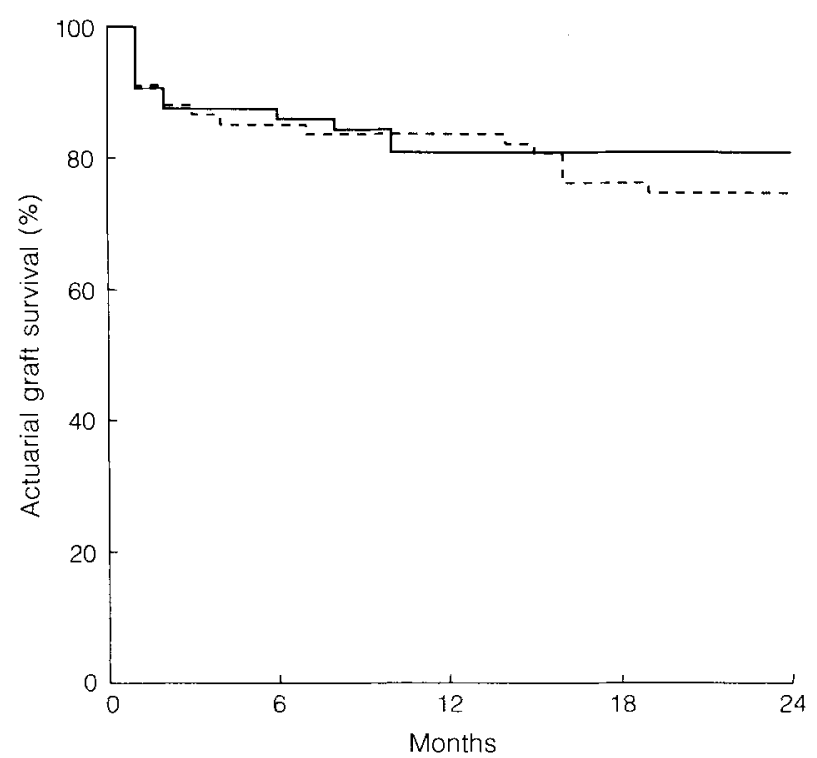

Fig.3. Actuarial graft survival curve after renal transplantation in patients treated with cyclosporin with (-) or without (---) a single dose of rabbit ATG

and a return to greater than $100 / \mathrm{mm}^{3}$ was observed at a median of 7 days (range 3-21 days; Fig. 2).

No difference in graft survival was found between the two treatment groups (Fig. 3). The incidence of primary nonfunction, defined as the need for dialysis treatment following transplantation, was $28 \%(16 / 58)$ in the r-ATGtreated patients, which was comparable to that in the CyA group. When dividing transplants with primary nonfunction into two groups, i.e., those that never functioned and had to be removed, and those functioning after a delay of several days or weeks, there was a tendency towards a lower frequency of delayed graft function and towards a higher number of never functioning grafts in the r-ATG groups, neither of which reached statistical significance. A total of seven grafts never functioned and were removed. Histological examination of these grafts following transplantectomy revealed vascular thrombosis and necrosis in three patients, one of whom had received two kidneys from a 3-year-old infant transplanted en bloc. In the other four patients with primary nonfunction, tubular damage and necrosis was observed, which could have been caused by either perfusion damage or vascular thrombosis. No immunoglobulin deposits suggestive of accelerated humoral rejection were found.

The incidence of biopsy-proven acute rejection following $\mathrm{r}$-ATG was $12 \%(7 / 58)$, which was lower than the rejection rate in the CyA group $(P<0.05$; Table 2$)$. All rejection episodes occurred more than 5 days after $r-A T G$ treatment and were successfully treated with a 10-day course of the same r-ATG preparation in a dose of $4 \mathrm{mg} / \mathrm{kg}$ in four patients and $1000 \mathrm{mg}$ methylprednisolone on 3 consecutive days in four patients. No correlation was observed between the occurrence of rejection and the time of reappearance of ' $\mathrm{T}$ cells in the peripheral blood.

Failure due to recurrent disease (mesangiocapillary glomerulonephritis and focal segmental glomerular sclerosis) was observed in two of the patients, 1 and 2 months after transplantation, respectively.

\section{Discussion}

The results of our study indicate that prophylaxis with a single shot of r-ATG leads to acceptable results. Graft survival was comparable to that in patients treated previously with either CyA or T-cell prophylaxis with h-ALG [6] or OKT3 [8]. After a single dose of r-ATG, we observed a low rate of acute rejection, lower than in patients treated with $\mathrm{Cy} A$ alone. It must be stressed that our study was not performed prospectively, and therefore caution must be observed when interpreting the results. The incidence of primary nonfunction was the same in both groups. Delayed graft function tended to occur more frequently in the CyA group. An interesting observation in our study

Table 2. Treatment outcome

\begin{tabular}{lccl}
\hline Patient group & $\begin{array}{l}\text { CyA-treated } \\
(n=56)\end{array}$ & $\begin{array}{l}\text { r-ATG-treated } \\
(n=58)\end{array}$ & $P$ value \\
\hline $\begin{array}{l}\text { CMV disease } \\
\begin{array}{l}\text { Urinary tract } \\
\text { infections }\end{array}\end{array}$ & $10(18 \%)$ & $5(8 \%)$ & NS \\
$\begin{array}{l}\text { Primary nonfunction } \\
- \text { Never functioning }\end{array}$ & $\begin{array}{l}22(40 \%) \\
\text { grafts }\end{array}$ & $16(28 \%)$ & NS \\
$\begin{array}{l}\text { Delayed graft } \\
\text { function }\end{array}$ & $5(9 \%)$ & $7(12 \%)$ & NS \\
$\begin{array}{l}\text { Acute rejection } \\
(<3 \text { months })\end{array}$ & $14(25 \%)$ & $9(15 \%)$ & NS \\
\hline
\end{tabular}


was the tendency towards a higher incidence of never functioning grafts due to thrombosis in the r-ATG group. This could be of special interest in light of a recent report by Abramowicz et al. [1]. They observed a $10 \%$ occurrence of intragraft thrombosis within 2 weeks of transplantation following the administration of OKT3 at a dose of $10 \mathrm{mg} /$ day.

Following the administration of a single dose of r-ATG, $T$ cells quickly disappeared from the circulation. It is interesting that the half-life of specific $\mathrm{r}$-IgG was much shorter than that of total IgG. This could have been the result of clearance of specific IgG due to T-cell destruction [2]. These results demonstrate that the measurement of total circulating rabbit immunoglobulin overestimates the effective plasma levels of r-ATG. Despite this rapid clearance of specific r-ATG, the number of circulating T cells remained low for 5-14 days, leading to an effective prophylactic period. Treatment with a single shot of r-ATG at a cost of $\$ 1500$ was considerably cheaper than a 7-day course of either horse ALG or OKT3 at a cost of $\$ 4000$ each.

We conclude that a single shot of $\mathbf{r}-\mathrm{ATG}$ is an attractive, easy, and cost-effective induction scheme with a low incidence of delayed graft function and acute rejection episodes. A relatively high incidence of vascular thrombosis of the graft, however, warrants further study before this treatment regimen can be generally applied.

\section{References}

1. Abramowicz D, Pradier O, Marchant A, Florquin S, De Pauw L, Vereerstraeten $P$, Kinnaert $P$, Vanherweghem JL, Goldman M (1992) Induction of thromboses within the renal grafts by highdose prophylactic OKT3. Lancet 339: 777-778

2. Bieber CP, Griep RB, Oyer PE, Wong J, Stinson EB (1976) Use of rabbit antithymocyte globulin in cardiac transplantation. Transplantation 22: 478-482

3. Cohen DJ, Benvenisty AI, Cianci J, Hardy MA (1989) OKT3 prophylaxis in cadaveric kidney transplant recipients with delayed graft function. Am J Kidney Dis 5 [Suppl 2]: 19-25

4. Kreeftenberg JG (1979) Rabbit anti-human-thymocyte globulin: production, control and clinical considerations. PhD Thesis, Amsterdam

5. Shield AGR, Kelly GE, Storey BG (1979) Use of antithymocyte globulin for reversal of acute allograft rejection. Transplantation 28: 461-467

6. Stratta RJ, D'Allessandro AM, Armhurst MJ, Pirsch JD, Sollinger HW, Kalayoglu M, Belzer FO (1989) Sequential antilymphocyte globulin/cyclosporine immunosuppression in cadaveric renal transplantation. Transplantation 47: 96-102

7. Weimar W, Hendriks GFJ, Wenting GJ, Vincent HH, Schreuder GMT, Jeekel J (1987) Prophylactic antilymphocyte globulin and HLA-DR matching reduce the incidence of rejection after cadaveric kidney transplantation. Transplant Proc 5: 3612-3613

8. Weimar W, Hesse CJ, Vaessen LM, Hendriks GFJ, Jutte NHPM, Jeekel J (1990) Rejection prophylaxis with sequential OKT3 and CSA after kidney transplantation. Biotherapy 2: 267-270 